\title{
Analytic Approach to Assessment of Interdependency of Economic Indicators (Statistical Method)
}

\author{
Goran Mitrović ${ }^{*}$, Slobodan Subotić ${ }^{2}$ \\ ${ }^{I}$ Drina Insurance a.d. Milici, Republic of Srpska, B\&H \\ ${ }^{2}$ University of East Sarajevo, Faculty of Transportation Doboj, Doboj, Republic of Srpska, B\&H
}

*Corresponding Author: Goran Mitrović, Drina Insurance a.d. Milici, Republic of Srpska, B\&H

\begin{abstract}
The subject of research conducted and included in this paper covers certain Western Balkan countries (Bosnia and Herzegovina, Montenegro and North Macedonia). The quantitative and qualitative macroeconomic indicators in the respective Western Balkan countries have been assessed by means of applying certain methods. Contemporary statistical methods have been applied in analyzing the conjunction and mutual dependency of these countries' economies, thereby indicating unique macroeconomic indicators of their efficiency and effectiveness. In that respect, indicators of gross domestic product, exports, imports and foreign direct investment have been presented both by using tables and various charts, covering the period from year 2000 to 2016. The analysis is based on the implementation of the econometric statistical methods of correlation and regression, as well as on the following statistic software suites: IBM SPSS ver. 21, Microsoft XLSTAT and 3B Stat ver. 1.01. A particular segment of the analysis of unique macroeconomic indicators is the comparison of the operational effectiveness of analyzed countries' economies, as well as their rankings on the basis of each of the relevant parameters. In that respect, respective unique indicators, in addition to absolute amounts, have also been provided as per capita calculations for the purpose of obtaining more realistic insight into the relative capacity of each of the respective Western Balkan countries.
\end{abstract}

Keywords: regression, correlation, statistic software suite.

\section{INTRODUCTION}

Correlation is a mutual relation of different phenomena presented by values in two or more random variables. This connection means that it is possible, with a certain degree of probability, to predict the value of a variable on the basis of the known value of another variable. The results (values) obtained can be presented in a chart (scatter plot) or by correlation coefficient. Regression analysis is one of the most commonly used statistical techniques and is considerably more complex than the correlation analysis as it represents its further elaboration. This analysis is a set of analytical techniques that are used for a more comprehensive understanding of the interdependence of observed phenomena, which further results in a regression equation (Mikić \& Ralević, 2006).

The paper contains a correlation and regression analysis of macroeconomic indicators related to the Western Balkan countries (Bosnia and Herzegovina, Montenegro and North Macedonia), particularly focusing on the following: 1) Gross domestic product (GDP), 2) export, 3) import and 4) Foreign Direct Investment (FDI).

Research and statistical analyses cover the period from the year 2000 to 2016, whereas the respective data had been initially appropriated based on certain econometric and statistical methods, in order to become suitable for obtaining specific conclusions. Namely, all of the data observed did demonstrate a remarkably unsteady trend, which was verified by means of the Augmented - Dickey - Fuller test, which is a violation of the premises for application of the regression analysis. One of the methods for resolving this issue was through logarithmic differentiation of data from successive time series. This method is used to observe the relative growth of observed phenomena instead of their specific levels. The initial data were acceptable for calculation and charts (graphic displays) of descriptive indicators, whereas the appropriated data were used for regression and correlation analysis. The analyses have been performed by means of the following statistic software suites IBM SPSS ver. 21, Microsoft XLSTAT and 3B Stat ver. 1.01. 


\section{ANALYTICAL APPROACH TO RELATIONSHIP AND LINKS BETWEeN MACROECONIMC INDICATORS IN WESTERN BALKAN COUNTRIES}

\subsection{Macroeconomic Indicators of Economy of Bosnia and Herzegovina}

Analyzed macroeconomic indicators of Bosnia and Herzegovina are presented in the table 1 and represent various levels of a certain phenomenon per year.

Table1: Macroeconomic indicators in Bosnia and Herzegovina (bn. USD)

\begin{tabular}{|l|l|l|l|l|}
\hline YEAR & GDP & EXPORT & IMPORT & FDI \\
\hline 2000 & 5,5 & 1,57795 & 4,1525 & 0,15 \\
\hline 2001 & 5,74 & 1,629586 & 4,357808 & 0,12 \\
\hline 2002 & 6,65 & 1,61861 & 4,71618 & 0,27 \\
\hline 2003 & 8,37 & 2,534436 & 6,960492 & 0,38 \\
\hline 2004 & 10,02 & 3,230448 & 7,764498 & 0,89 \\
\hline 2005 & 11,22 & 3,547764 & 8,035764 & 0,62 \\
\hline 2006 & 12,86 & 4,502286 & 8,103086 & 0,85 \\
\hline 2007 & 15,77 & 4,27367 & 8,902165 & 1,84 \\
\hline 2008 & 19,33 & 5,188172 & 11,46462 & 1 \\
\hline 2009 & 17,61 & 4,4025 & 8,581353 & 0,14 \\
\hline 2010 & 17,17 & 5,097773 & 8,803059 & 0,44 \\
\hline 2011 & 18,64 & 5,970392 & 10,40112 & 0,47 \\
\hline 2012 & 17,22 & 5,568948 & 9,61737 & 0,4 \\
\hline 2013 & 18,47 & 6,231778 & 9,997811 & 0,31 \\
\hline 2014 & 18,58 & 6,315342 & 10,52929 & 0,55 \\
\hline 2015 & 16,21 & 5,603797 & 8,628583 & 0,37 \\
\hline 2016 & 16,91 & 5,987831 & 8,842239 & 0,27 \\
\hline
\end{tabular}

Source: http/worldbank.org/indikator/bx.klt.dinv.cd.wd

The descriptive analysis of Bosnia and Herzegovina's macroeconomic status shows the minimum values of all the observed variables were noted at the very beginning of the assessed period, whereas the maximum values were reached in the middle of the assessed period. The average GDP amounts to 13,898 billion USD, while the average value of export amounts to 4,311 billion USD, whereas the import equals to 8,227 billion USD. The average amount of FDI per year is 0,534 billion USD.

Table2: Descriptive indicators - Bosnia and Herzegovina

\begin{tabular}{|l|l|l|l|l|}
\hline \multicolumn{1}{|c|}{ STATISTIC } & \multicolumn{1}{c|}{ GDP } & \multicolumn{1}{c|}{ EXPORT } & \multicolumn{1}{c|}{ IMPORT } & \multicolumn{1}{c|}{ FDI } \\
\hline No. of observations & 17 & 17 & 17 & 17 \\
\hline Minimum & 5,500 & 1,578 & 4,153 & 0,120 \\
\hline Maximum & 19,330 & 6,315 & 11,465 & 1,840 \\
\hline Median & 16,210 & 4,502 & 8,629 & 0,400 \\
\hline Mean & 13,898 & 4,311 & 8,227 & 0,534 \\
\hline Standard deviation (n-1) & 4,948 & 1,673 & 2,133 & 0,426 \\
\hline
\end{tabular}

Source: Table generated by the author

The movement of observed macroeconomic indicators is more clearly shown by the graphic illustration of data derived from Table 2. The chart shows that FDI reached their maximum in year 2006, and consequently the value of FDI, exports and imports reached their peak value in the following year. The world economic crisis, which struck afterwards, significantly influenced the decline of all macroeconomic parameters, as clearly shown on the chart.

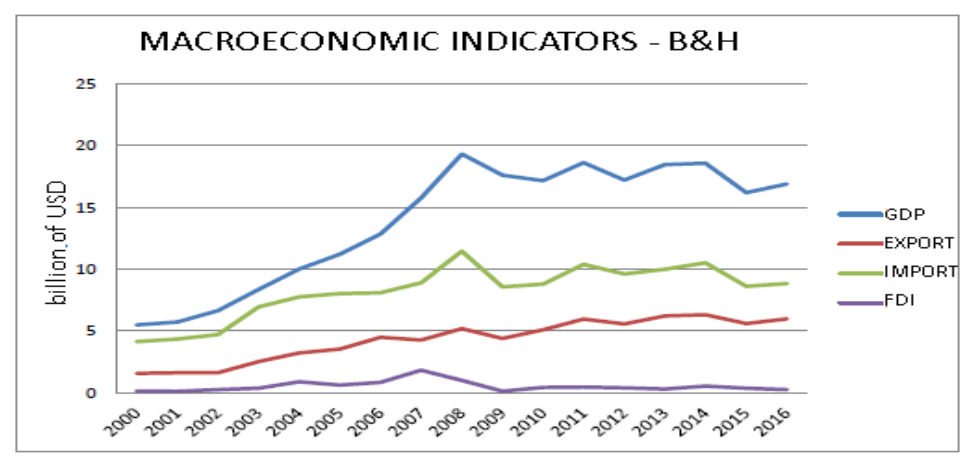

Chart1: Trend of macroeconomic indicators - Bosnia and Herzegovina 
The results of the regression and correlation analyses have been shown in the following tables. Based on the data from the Table 3 , it is evident that there is a statistically significant correlation link between GDP and exports and GDP and imports ( $\mathrm{r} h o=0,626$ and $r h o=0,809$ ), whereas there is no statistically significant link between FDI and GDP. Both of the correlation coefficients are positive, thus indicating that the subject relationship is direct, i.e. that the growth of one dependent variable consequently increases the value of the other one.

Table3: Spearman's correlation coefficients - Bosnia and Herzegovina

\begin{tabular}{|l|l|l|l|l|l|l|}
\hline \multicolumn{9}{|c|}{ Correlations } \\
\hline \multirow{2}{*}{$\begin{array}{l}\text { Spearman's } \\
\text { rho }\end{array}$} & GDP-BH & $\begin{array}{l}\text { GDP-BH } \\
\text { Correlation } \\
\text { Coefficient }\end{array}$ & 1,000 & $\mathbf{E X P O R T - B H}$ & IMPORT-BH & FDI-BH \\
\cline { 2 - 7 } & $\begin{array}{l}\text { EXPORT- } \\
\text { BH }\end{array}$ & $\begin{array}{l}\text { Correlation } \\
\text { Coefficient }\end{array}$ & $0,626^{* *}$ & 1,000 & $0,809^{* *}$ & 0,344 \\
\cline { 2 - 7 } & $\begin{array}{l}\text { IMPORT- } \\
\text { BH }\end{array}$ & $\begin{array}{l}\text { Correlation } \\
\text { Coefficient }\end{array}$ & $0,809^{* * *}$ & $0,597^{*}$ & $0,597^{* *}$ & 0,309 \\
\cline { 2 - 7 } & FDI-BH & $\begin{array}{l}\text { Correlation } \\
\text { Coefficient }\end{array}$ & 0,344 & 0,309 & 0,388 & 0,388 \\
\hline
\end{tabular}

Source: Table generated by the author

The regression analysis showed that $61,7 \%$ of GDP variability is determined by the variability of other assessed macroeconomic indicators, i.e., by a respective model. This outcome is statistically significant, as confirmed by the $\mathrm{F}$ test $(F=9,069 ; p$ value $=0,002)$.

Table4: The value of the coefficient of determination - Bosnia and Herzegovina

\begin{tabular}{|l|l|l|l|l|}
\hline \multicolumn{5}{|c|}{ Model Summary $^{\mathbf{b}}$} \\
\hline \multicolumn{1}{|c|}{ Model } & \multicolumn{1}{|c|}{$\mathbf{R}$} & \multicolumn{1}{c|}{ R Square } & \multicolumn{1}{|c|}{ Adjusted R Square } & Std. Error of the Estimate \\
\hline 1 & $0,833^{\mathrm{a}}$ & 0,694 & 0,617 & 0,0303978 \\
\hline a. Predictors: (Constant), FDI-BH, EXPORT-BH, IMPORT-BH \\
\hline
\end{tabular}

Source: Table generated by the author

$\mathrm{B}$ and $\beta$ coefficients, as well as the regression equation were calculated and presented. Table 5 shows the results obtained. It should be noted that only $\mathrm{B}_{2}$ value is statistically significant, that is, that only "import" variable provides a unique statistically significant contribution to the regression equation ( $p$ value 0,017).

Table5: Multiple linear regression coefficients - Bosnia and Herzegovina

\begin{tabular}{|c|c|c|c|c|c|c|c|c|}
\hline \multicolumn{9}{|c|}{ Coefficients $^{\text {a }}$} \\
\hline \multirow{2}{*}{\multicolumn{2}{|c|}{ Model }} & \multicolumn{2}{|c|}{$\begin{array}{c}\text { Unstandardized } \\
\text { Coefficients }\end{array}$} & \multirow{2}{*}{$\begin{array}{c}\begin{array}{c}\text { Standardized } \\
\text { Coefficients }\end{array} \\
\text { Beta }\end{array}$} & \multirow[t]{2}{*}{$\mathbf{t}$} & \multirow[t]{2}{*}{ Sig. } & \multicolumn{2}{|c|}{$\begin{array}{c}\text { Collinearity } \\
\text { Statistics }\end{array}$} \\
\hline & & $\mathrm{B}$ & Std. Error & & & & Tolerance & VIF \\
\hline \multirow[t]{4}{*}{1} & (Constant) & 0,018 & 0,009 & & 2,010 & 0,067 & & \\
\hline & EXPORT-BH & 0,019 & 0,201 & 0,026 & 0,093 & 0,927 & 0,332 & 3,016 \\
\hline & IMPORT-BH & 0,578 & 00,209 & 0,805 & 2,758 & 0,017 & 0,299 & 3,343 \\
\hline & FDI-BH & 0,002 & 0,027 & 0,013 & 0,072 & 0,944 & 0,762 & 1,313 \\
\hline
\end{tabular}

Source: Table generated by the author

The values of standardized $\beta$ coefficients speak in favor of the above, as it is clear that the impact of import is 0,805 , of export 0,026 , and of FDI only 0,013 . The regression equation is as follows:

$$
Y=0,018+0,019 * X_{1}+0,0578 * X_{2}+0,002 * X_{3}
$$

The equation is interpreted in a way that a 1 billion USD increase in import will cause the GDP growth of 0,578 billion USD, should the remaining variables remain unchanged. The same principle applies to the other two coefficients included in the regression equation.

\subsection{Macroeconomic Indicators of Montenegro Economy}

Information on the trend of macroeconomic indicators in Montenegro are provided in Table 6. It is important to stress that the information on FDI in the year 2000 and 2001 were not available, resulting 
in the preparation of certain assessments for other macroeconomic indicators excluding the information from those two years.

Table6: Macroeconomic indicators - Montenegro (billions of USD)

\begin{tabular}{|l|l|l|l|l|}
\hline YEAR & GDP & EXPORT & IMPORT & FDI \\
\hline 2000 & 0,98 & 0,360738 & 0,500878 & - \\
\hline 2001 & 1,16 & 0,445672 & 0,718968 & - \\
\hline 2002 & 1,28 & 0,452608 & 0,766464 & 0,07 \\
\hline 2003 & 1,7 & 0,52037 & 0,79866 & 0,05 \\
\hline 2004 & 2,07 & 0,869814 & 1,202256 & 0,07 \\
\hline 2005 & 2,25 & 1,053 & 1,374075 & 0,05 \\
\hline 2006 & 1,303305 & 2,127521 & 0,62 \\
\hline 2007 & 2,69 & 1,604157 & 3,181523 & 0,94 \\
\hline 2008 & 1,794208 & 4,214028 & 0,98 \\
\hline 2009 & 1,424695 & 2,701235 & 1,55 \\
\hline 2010 & 4,67 & 1,522344 & 2,578203 & 0,76 \\
\hline 2011 & 4,54 & 1,9053 & 2,89395 & 0,56 \\
\hline 2012 & 4,11 & 1,781736 & 2,778072 & 0,61 \\
\hline 2013 & 1,843764 & 2,739332 & 0,45 \\
\hline 2014 & 4,08 & 1,838412 & 2,747084 & 0,5 \\
\hline 2015 & 4,46 & 1,705455 & 2,453085 & 0,7 \\
\hline 2016 & 4,58 & 1,768102 & 2,749604 & 0,27 \\
\hline
\end{tabular}

Source: http/worldbank.org/indikator/bx.klt.dinv.cd.wd

Descriptive analysis results are almost identical as with the previously assessed country. The minimum values were registered at the very beginning of the assessed period, whereas the maximum values were reached in the final years. However, FDI should be exempt from the above statement, as the FDI reached their maximum values in the middle of the assessed period, namely in 2009. The average GDP amounts to 3,214 billion USD, while the average value of export amounts to 1,306 billion USD, whereas the import equals to 2,149 billion USD.

Table7: Descriptive indicators - Montenegro

\begin{tabular}{|l|l|l|l|l|}
\hline \multicolumn{1}{|c|}{ STATISTIC } & \multicolumn{1}{c|}{ GDP } & \multicolumn{1}{c|}{ EXPORT } & \multicolumn{1}{c|}{ IMPORT } & \multicolumn{1}{c|}{ FDI } \\
\hline No. of observations & 17 & 17 & 17 & 17 \\
\hline Minimum & 0,980 & 0,361 & 0,501 & 0,050 \\
\hline Maximum & 4,580 & 1,905 & 4,214 & 1,550 \\
\hline Median & 4,050 & 1,522 & 2,578 & 0,560 \\
\hline Mean & 3,214 & 1,306 & 2,149 & 0,545 \\
\hline Standard deviation (n-1) & 1,352 & 0,567 & 1,058 & 0,419 \\
\hline Variation coefficient & 0,408 & 0,422 & 0,478 & 0,743 \\
\hline
\end{tabular}

Source: Table generated by the author

The following chart provides insight into the trends of the assessed macroeconomic indicators.

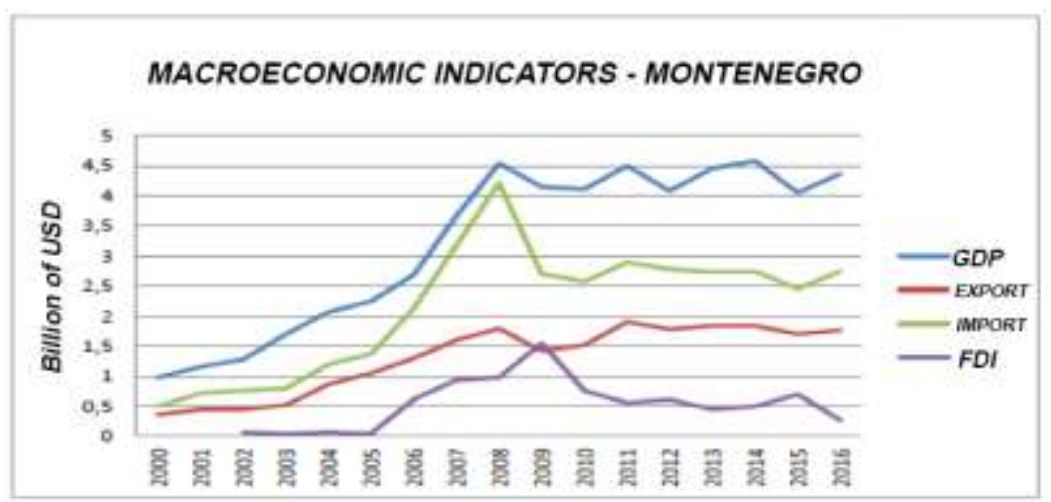

Chart2: Trend of macroeconomic indicators - Montenegro

Further analysis included calculation of correlation coefficient and regression equation. By means of correlation, it was established that there is a statistically significant link between GDP and import, as 
well as between GDP and export (rho=0,724 and rho=0,785). Likewise, both import and export are mutually related by means of direct correlation $\mathrm{rho}=0,859$, whereas FDI have no statistically relevant correlation coefficient with any of the variables.

Table8: Spearman correlation coefficient-Montenegro

\begin{tabular}{|l|l|l|l|l|l|l|}
\hline \multicolumn{9}{|c|}{\begin{tabular}{c} 
Correlations \\
\multicolumn{2}{|c|}{}
\end{tabular}} & $\begin{array}{c}\text { FDP- } \\
\text { MNE }\end{array}$ & $\begin{array}{c}\text { EXPORT- } \\
\text { MNE }\end{array}$ & $\begin{array}{c}\text { IMPORT- } \\
\text { MNE }\end{array}$ & $\begin{array}{c}\text { FDI- } \\
\text { MNE }\end{array}$ \\
\hline \multirow{2}{*}{$\begin{array}{l}\text { Spearman's } \\
\text { rho }\end{array}$} & GDP-MNE & $\begin{array}{l}\text { Correlation } \\
\text { Coefficient }\end{array}$ & 1,000 & $0,724^{* * *}$ & $0,785^{* *}$ & 0,033 \\
\cline { 2 - 7 } & $\begin{array}{l}\text { EXPORT- } \\
\text { MNE }\end{array}$ & $\begin{array}{l}\text { Correlation } \\
\text { Coefficient }\end{array}$ & $0,724^{* *}$ & 1,000 & $0,859^{* *}$ &,- 040 \\
\cline { 2 - 7 } & $\begin{array}{l}\text { IMPORT- } \\
\text { MNE }\end{array}$ & $\begin{array}{l}\text { Correlation } \\
\text { Coefficient }\end{array}$ & $0,785^{* *}$ & $0,859^{* *}$ & 1,000 & 0,152 \\
\cline { 2 - 7 } & FDI-MNE & $\begin{array}{l}\text { Correlation } \\
\text { Coefficient }\end{array}$ & 0,033 & $-0,040$ & 0,152 & 1,000 \\
\hline
\end{tabular}

Source: Table generated by the author

The regression analysis results presented in Table 8 have shown that 50,50\% of GDP variability has been determined by the variability of independent variables. Likewise, this indicator may be considered as a statistically relevant items given the e $F$ test values $(F=5,420$ : $p$ value $=0,018)$.

Table9: The value of the coefficient of determination-Montenegro

\begin{tabular}{|l|l|l|l|l|}
\hline \multicolumn{5}{|c|}{ Model Summary $^{\mathbf{b}}$} \\
\hline \multicolumn{1}{|c|}{ Model } & \multicolumn{1}{|c|}{$\mathbf{R}$} & \multicolumn{1}{c|}{ R Square } & \multicolumn{1}{|c|}{ Adjusted R Square } & Std. Error of the Estimate \\
\hline 1 & $0,787^{\mathrm{a}}$ & 0,619 & 0,505 & 0,0397530 \\
\hline a. Predictors: (Constant), FDI-CG, EXPORT-CG, IMPORT-CG \\
\hline \multicolumn{2}{|l}{ b. Dependent Variable: GDP-CG } \\
\hline
\end{tabular}

Source: Table generated by the author

On the basis of the remaining regression analysis indicators, it can be stated that the GDP is predominantly influenced by import, followed by export, and only then by FDI. The important matter is that none of these indicators bears no statistical relevance, i.e. none of them may be marked as an indicator featuring a unique and statistically significant contribution to the regression equation.

Table10: Multiple linear regression coefficients - Montenegro

\begin{tabular}{|c|c|c|c|c|c|c|c|c|}
\hline & \multicolumn{8}{|c|}{ Coefficients $^{\mathrm{a}}$} \\
\hline & \multirow[t]{2}{*}{ Model } & \multicolumn{2}{|c|}{$\begin{array}{c}\text { Unstandardized } \\
\text { Coefficients }\end{array}$} & \multirow{2}{*}{$\begin{array}{c}\begin{array}{c}\text { Standardized } \\
\text { Coefficients }\end{array} \\
\text { Beta }\end{array}$} & \multirow[t]{2}{*}{$t$} & \multirow[t]{2}{*}{ Sig. } & \multicolumn{2}{|c|}{$\begin{array}{c}\text { Collinearity } \\
\text { Statistics }\end{array}$} \\
\hline & & B & Std. Error & & & & Tolerance & VIF \\
\hline \multirow[t]{4}{*}{1} & (Constant) & 0,019 & 0,012 & & 1,509 & 0,162 & & \\
\hline & $\begin{array}{l}\text { EXPORT- } \\
\text { CG }\end{array}$ & 0,102 & 0,294 & 0,132 & 0,346 & 0,737 & 0,261 & 3,835 \\
\hline & $\begin{array}{l}\text { IMPORT- } \\
\text { CG }\end{array}$ & 0,393 & 0,226 & 0,703 & 1,742 & 0,112 & 0,234 & 4,281 \\
\hline & FDI-CG & $-0,020$ & 0,035 & $-0,124$ & $-0,568$ & 0,583 & 0,795 & 1,258 \\
\hline
\end{tabular}

a. Dependent Variable: GDP-CG

Source: Table generated by the author

Based on the information shown in the table above, a multiple regression equation may be generated as follows:

$$
\mathbf{Y}=0,019+0,102 * X_{1}+0,393 * X_{2}-0,020 * X_{3}
$$

The equation shows that the growth of both import and export would result in a growth of GDP (positive symbol placed before B coefficient) whereas FDI growth would influence GDP in an opposite manner.

\subsection{Macroeconomic Indicators of the Economy of North Macedonia}

The last country assessed is North Macedonia, whose macroeconomic indicators are shown in the following table. 
Analytic Approach to Assessment of Interdependency of Economic Indicators (Statistical Method)

Table11: Macroeconomic indicators - North Macedonia (billions of USD)

\begin{tabular}{|l|l|l|l|l|}
\hline \multicolumn{1}{|c|}{ YEAR } & \multicolumn{1}{c|}{ GDP } & \multicolumn{1}{c|}{ EXPORT } & \multicolumn{1}{c|}{ IMPORT } & \multicolumn{1}{c|}{ FDI } \\
\hline 2000 & 3,77 & 1,241838 & 1,779817 & 0,22 \\
\hline 2001 & 3,71 & 1,082949 & 1,568217 & 0,47 \\
\hline 2002 & 4,18 & 1,09934 & 1,890614 & 0,11 \\
\hline 2003 & 4,94 & 1,36591 & 2,144454 & 0,12 \\
\hline 2004 & 5,68 & 1,74376 & 2,849088 & 0,3 \\
\hline 2005 & 6,25 & 2,175 & 3,189375 & 0,14 \\
\hline 2006 & 6,86 & 2,592394 & 3,756536 & 0,42 \\
\hline 2007 & 8,33 & 3,674363 & 5,162101 & 0,73 \\
\hline 2008 & 9,91 & 4,283102 & 6,772494 & 0,61 \\
\hline 2009 & 9,4 & 3,2712 & 5,11078 & 0,26 \\
\hline 2010 & 9,4 & 4,74026 & 5,46046 & 0,3 \\
\hline 2011 & 10,4 & 4,419038 & 6,87024 & 0,5 \\
\hline 2012 & 9,74 & 4,690459 & 6,510216 & 0,38 \\
\hline 2013 & 10,81 & 5,414176 & 6,643826 & 0,4 \\
\hline 2014 & 11,36 & 4,9044 & 7,369232 & 0,6 \\
\hline 2015 & 10,05 & 5,36716 & 6,53451 & 0,3 \\
\hline 2016 & 10,9 & 6,95311 & 0,55 \\
\hline
\end{tabular}

Source: http/worldbank.org/indikator/bx.klt.dinv.cd.wd

Descriptive analysis indicators, as shown in Table 11, indicate similar trends as with other assessed countries, save for the FDI, where no notable trend of increase was registered. Secondly, it should be pointed out that the FDI level is lower even when compared to Montenegro, while average values of GDP, export and import are significantly higher.

Table12: Descriptive indicators - North Macedonia

\begin{tabular}{|l|l|l|l|l|}
\hline \multicolumn{1}{|c|}{ STATISTIC } & \multicolumn{1}{c|}{ GDP } & \multicolumn{1}{c|}{ EXPORT } & \multicolumn{1}{c|}{ IMPORT } & \multicolumn{1}{c|}{ FDI } \\
\hline No. of observations & 17 & 17 & 17 & 0,110 \\
\hline Minimum & 3,710 & 1,083 & 1,568 & 0,730 \\
\hline Maximum & 11,360 & 5,414 & 7,369 & 0,380 \\
\hline Median & 9,400 & 3,674 & 5,162 & 0,377 \\
\hline Mean & 7,982 & 3,292 & 4,739 & 0,183 \\
\hline Standard deviation (n-1) & 2,719 & 1,587 & 2,120 & 0,470 \\
\hline Variation coefficient & 0,330 & 0,468 & 0,434 & \\
\hline
\end{tabular}

Source: Table generated by the author

Dana chart clearly shows an increase of the first three macroeconomic indicators, whereas the FDI variable constantly remains within $0-0,5$ billion USD range. It is evident that GDP growth does not follow the increase in FDI, as the latter are not the key determinant in GDP growth, which will be further supported by the subsequent analyses.

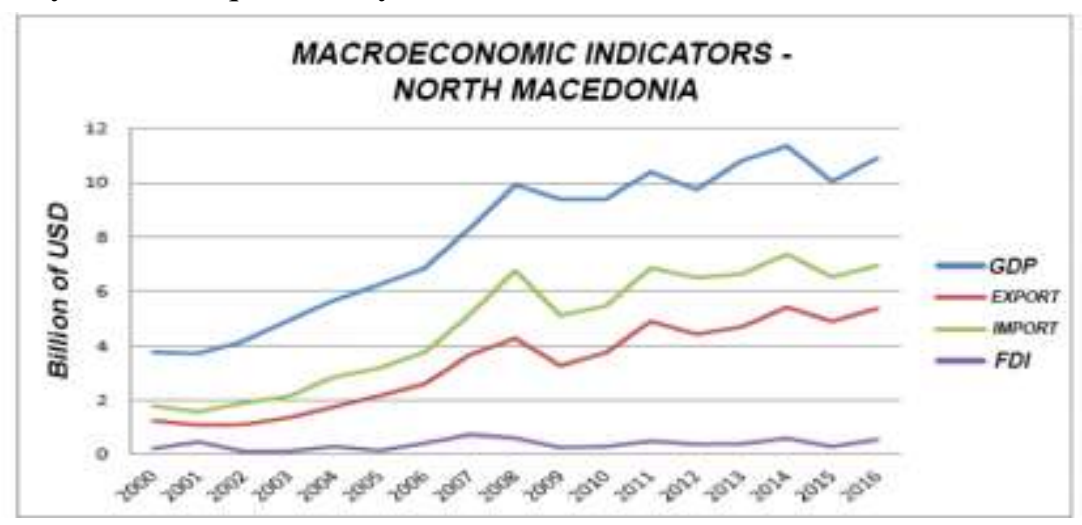

Chart3: Trend of macroeconomic indicators - North Macedonia

Table13: Spearman correlation coefficient-North Macedonia

\begin{tabular}{|c|c|c|c|c|c|c|}
\hline \multicolumn{7}{|c|}{ Correlations } \\
\hline & & & $\begin{array}{l}\text { GDP- } \\
\text { MKD }\end{array}$ & $\begin{array}{l}\text { EXPORT- } \\
\text { MKD }\end{array}$ & $\begin{array}{l}\text { IMPORT- } \\
\text { MKD }\end{array}$ & $\begin{array}{l}\text { FDI- } \\
\text { MKD }\end{array}$ \\
\hline Spearman's & GDP-MKD & Correlation & 1,000 & $0,721^{*}$ & $0,853^{\text {*** }}$ & 0,174 \\
\hline
\end{tabular}




\begin{tabular}{|l|l|l|l|l|l|l|}
\hline \multirow{3}{*}{ rho } & & Coefficient & & & & \\
\cline { 2 - 7 } & $\begin{array}{l}\text { EXPORT- } \\
\text { MKD }\end{array}$ & $\begin{array}{l}\text { Correlation } \\
\text { Coefficient }\end{array}$ & $0,721^{* *}$ & 1,000 & $0,859^{* *}$ & 0,421 \\
\cline { 2 - 7 } & $\begin{array}{l}\text { IMPORT- } \\
\text { MKD }\end{array}$ & $\begin{array}{l}\text { Correlation } \\
\text { Coefficient }\end{array}$ & $0,853^{* *}$ & $0,859^{* *}$ & 1,000 & 0,297 \\
\cline { 2 - 6 } & FDI-MKD & $\begin{array}{l}\text { Correlation } \\
\text { Coefficient }\end{array}$ & 0,174 & 0,421 & 0,297 & 1,000 \\
\hline
\end{tabular}

Source: Table created by the author

Further assessment included both correlation and regression analysis, the results of which have been provided in the following tables. Spearman correlation coefficient data indicate the presence of a direct and statistically significant correlation link between GDP and export, as well as between GDP and import (rho=0,721 and rho=0,853). As presumed before, the link between FDI and other variables bears no statistical significance.

Table14: The value of the coefficient of determination - North Macedonia

\begin{tabular}{|l|l|l|l|l|}
\hline \multicolumn{5}{|c|}{ Model Summary $^{\mathbf{b}}$} \\
\hline \multicolumn{1}{|c|}{ Model } & $\mathbf{R}$ & \multicolumn{1}{|c|}{ R Square } & \multicolumn{1}{|c|}{ Adjusted R Square } & Std. Error of the Estimate \\
\hline 1 & $0,859^{\mathrm{a}}$ & 0,738 & 0,672 & 0,0230891 \\
\hline a. Predictors: (Constant), FDI-MKD, IMPORT-MKD, EXPORT-MKD \\
\hline \multicolumn{4}{|l}{ b. Dependent Variable: GDP-MKD } \\
\hline
\end{tabular}

Source: Table created by the author

The regression analysis proved that $67,20 \%$ of GDP variability is determined by the variability of other assessed macroeconomic indicators. This information is statistically significant, as the $\mathrm{F}$ test value amounts to 11,254 and the $\mathrm{p}$ value equals 0,002 .

Table15: Multiple linear regression coefficients - North Macedonia

\begin{tabular}{|c|c|c|c|c|c|c|c|c|}
\hline \multicolumn{9}{|c|}{ Coefficients $^{\mathrm{a}}$} \\
\hline \multirow{2}{*}{\multicolumn{2}{|c|}{ Model }} & \multicolumn{2}{|c|}{$\begin{array}{l}\text { Unstandardized } \\
\text { Coefficients }\end{array}$} & \multirow{2}{*}{$\begin{array}{l}\text { Standardized } \\
\text { Coefficients } \\
\text { Beta }\end{array}$} & \multirow[t]{2}{*}{$\mathbf{t}$} & \multirow[t]{2}{*}{ Sig. } & \multicolumn{2}{|c|}{$\begin{array}{l}\text { Collinearity } \\
\text { Statistics }\end{array}$} \\
\hline & & B & Std. Error & & & & Tolerance & VIF \\
\hline \multirow[t]{4}{*}{1} & (Constant) & 0,010 & 0,007 & & 1,559 & 0,145 & & \\
\hline & $\begin{array}{l}\text { EXPORT- } \\
\text { MKD }\end{array}$ & 0,102 & 0,207 & 0,187 & 0,492 & 0,632 & 0,152 & 6,581 \\
\hline & $\begin{array}{l}\text { IMPORT- } \\
\text { MKD }\end{array}$ & 0,391 & 0,200 & 0,700 & 1,949 & 0,075 & 0,170 & 5,893 \\
\hline & FDI-MKD & $-0,005$ & 0,022 & $-0,039$ & $-0,232$ & 0,820 & 0,763 & 1,310 \\
\hline
\end{tabular}

Source: Table created by the author

Both regression equation coefficients and standardized coefficients have been calculated, indicating that the GDP was predominantly influenced by import, then by export, and ultimately by FDI. As in the previous analysis, by means of $\mathrm{F}$ test it was determined that these indicators have no statistical relevance. That is why it cannot be said that they bring unique contribution to the FGD variability. Regression equation obtained based on the calculated data is as follows:

$$
\mathbf{Y}=\mathbf{0 , 0 1 9 + 0 , 1 0 2} * \mathbf{X}_{1}+\mathbf{0}, 393 * \mathbf{X}_{2}-\mathbf{0 , 0 2 0} * \mathbf{X}_{3}
$$

This equation would, as in the analysis above, imply that the GDP growth is conditioned by the increase in import and export, whereas FDI are inversely proportional, meaning that the increase in FDI would reduce the GDP value.

\section{COMPARATiVe ANAlysis OF MaCroeconomic Indicators in Western Balkan COUNTRIES}

Comparative analysis of the gross domestic product indicators per capita is performed on the basis of indicators taken from the World Bank website, as shown in Table 16.

Table16: GDP per capita in Western Balkan countries and the EU (USD)

\begin{tabular}{|l|l|l|l|l|}
\hline \multicolumn{1}{|c|}{ Year } & \multicolumn{1}{c|}{ Montenegro } & Bosnia and Herz. & North Macedonia & EU \\
\hline 2000. & 1.627 & 1.462 & 1.854 & 18.244 \\
\hline
\end{tabular}


Analytic Approach to Assessment of Interdependency of Economic Indicators (Statistical Method)

\begin{tabular}{|l|l|l|l|l|}
\hline \multicolumn{5}{|l|}{} \\
\hline 2001. & 1.909 & 1.524 & 1.815 & 18.407 \\
\hline 2002. & 2,106 & 1.762 & 1.961 & 20.018 \\
\hline 2003. & 2.789 & 2.215 & 2.404 & 24.278 \\
\hline 2004. & 3.380 & 2.651 & 2.762 & 27.922 \\
\hline 2005. & 3.674 & 2.968 & 3.037 & 29.093 \\
\hline 2006. & 4.425 & 3.404 & 3.325 & 30.923 \\
\hline 2007. & 5.976 & 4.180 & 4.036 & 35.594 \\
\hline 2008. & 7.367 & 5.078 & 4.793 & 38.136 \\
\hline 2009. & 6.727 & 4.701 & 4.544 & 33.979 \\
\hline 2010. & 6.682 & 4.614 & 4.542 & 33.677 \\
\hline 2011. & 7.318 & 5.054 & 5.063 & 36.409 \\
\hline 2012. & 6.586 & 4.722 & 4.698 & 34.253 \\
\hline 2013. & 7.186 & 5.211 & 5.210 & 35.388 \\
\hline 2014. & 7.378 & 5.204 & 5.468 & 36.760 \\
\hline 2015. & 6.514 & 4.584 & 4.840 & 32.207 \\
\hline 2016. & 7.028 & 4.808 & 5.129 & 32.260 \\
\hline
\end{tabular}

Source: http/worldbank.org/indikator/bx.klt.dinv.cd.wd



Chart4: GDP trend per capita in the Western Balkan countries

By monitoring GDP trend per capita of the given three Western Balkans countries, and based on the indicators from Table 16, it can be said that the trend of GDP per capita of all the countries had risingfalling properties. All of the countries recorded GDP per capita decline in years 2009, 2010, 2012 and 2015. Bosnia and Herzegovina registered the largest decline of GDP per capita in 2015 by $11,91 \%$ compared to the year before. Montenegro, unlike Bosnia and Herzegovina, registered a less severe decline in GDP per capita in 2015, amounting to 11,70\%. A similar situation was also in North Macedonia, that registered the largest GDP decline per capita in $2015(11,48 \%)$ that was somewhat less intense than the one in Montenegro.

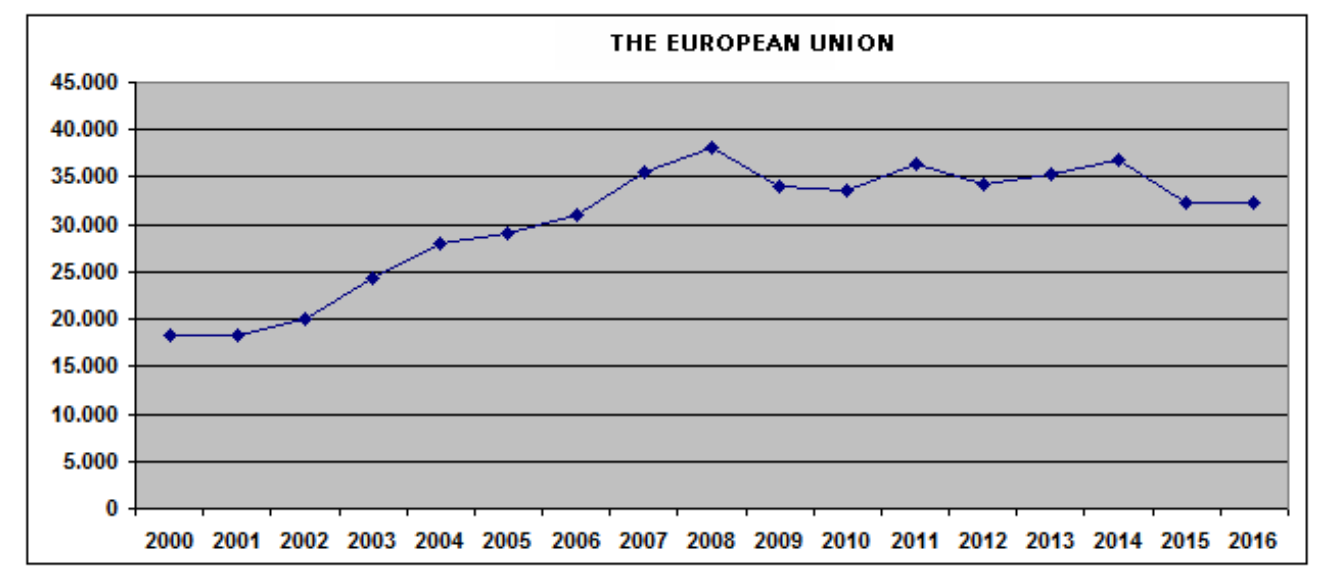

Chart5: GDP trend per capita in the $E U$

By analyzing the GDP trend per capita of the European Union (Table 16 and Chart 5), it becomes evident that the decline of this macroeconomic indicator has been recorded several times. The drastic 
decline of GDP per capita was notable in year 2009 by 10,90\% compared to 2008 . The mild drop of this indicator was recorded in year $2010(0,88 \%)$, whereas in 2012 the decline of GDP per capita amounted to $5,92 \%$, and in 2015 it was $12,38 \%$. It is important to point out that the decline of GDP per capita in the European Union was followed by the decline of this particular indicator in certain Western Balkan countries, with the most pronounced effect in 2015 as it was the case with the European Union. This indicates the existence of a cause and effect link of the European Union economies and of the subject Western Balkan countries' economies.

\section{CONCLUSION}

The countries observed share several distinctive macroeconomic indicators. It should be noted that the subject countries were under the great influence of the recession factors to the year 2000. The cause of a ten-year recession in the assessed countries was a very unfavorable political and state security situation, which caused a major decline in the economic activity, a decline in social and individual standards, a reduction in consumption and investment, and nearly the complete exclusion of foreign direct investment. All of the above factors resulted in a massive decline in GDP value.

Consolidation and establishment of elementary economic conditions have created preconditions for the significant growth of GDP percentage, which in some of the subject countries amounted even up to $20 \%$, which is very uncommon in stable and developed economies. The common feature for all of the three countries was that they all registered a high percentage of GDP growth over the period from 2000 to 2007, whereas in the second part of the assessed period (2008-2016), their GDP growth rates were significantly lower, sometimes stagnant, and even with a few cases of recession occurring on the global scale. The above is a completely normal sequence of events, given the fact that the first period, up to year 2007, the subject countries had used up their natural and comparative advantages in raising their economic activity. The reason for the slower GDP growth in the second part of the monitored period (2008-2016) lies in much greater exposure to the impacts of the world market, competitiveness, insufficient technological development, traffic infrastructure conditions, level of education system and other macroeconomic indicators.

The final conclusion related to the GDP growth of these countries is that all of them experienced a high level of growth expressed in absolute indications.

The next common feature of the observed countries of the Western Balkans is that each of them had a high foreign trade deficit that was the highest at the beginning of the monitored period (import coverage by export was $40 \%$ ), only for the foreign trade deficit to be significantly reduced in the following years (some countries have reached up to 85\%). The reason for the high foreign trade deficit lies in the fact that in the beginning of the assessed period there was a great increase in demand for goods that the local economy was not able to provide, i.e. the inability of the local economy to enable better import coverage by export.

By analyzing the set model from the aspect of FDI influence onto the GDP growth, it can be stated that in the initial observed period, the influence on GDP growth was less notable, as the predominant was the influence of the consolidation of the economic system and growth of the economic activity, as well as that the FDI had a positive effect initially. Over time the FDI had a growing impact on GDP growth in terms of enhancing the competitiveness of the assessed countries. Based on the research results, it can be concluded that in the upcoming period, FDI will have a continuously growing impact on GDP growth, as well as on the reduction and elimination of the foreign trade deficit.

The importance of FDI growth does not only lie in the fact that it positively affects GDP growth, but it also has a positive impact on the balance of payments as well as on the chronic issue of the countries suffering from a budget deficit. The FDI ultimately have a positive impact on the balance of complete public finances of the observed states. It can be said that the influx of FDI is far from the one that is possible to be achieved by utilizing comparative advantages of this region. It should be noted that the observed countries are still in the process of transition with currently ongoing risks (security risks, political risks, rule of law, corruption, implementation of international standards and other risks) that have an unfavorable impact on FDI influx. The elimination of those risks will manifest the most important preconditions that attract the FDI, particularly referring to the cheap labor, unused natural resources, geostrategic position, traffic infrastructure, market proximity, etc. 
Generally speaking, in all three assessed Western Balkan countries, regardless of their unequal level of economic development, descriptive indicators point to the conclusion that the changes in export and import significantly affect the value of GDP. The correlation analysis indicates a significant statistical link of GDP with the export and import variables in all of the subject countries. The results of the multiple linear regression coefficient show that the import variable, in all three countries, has the greatest statistical impact onto the regression equation, i.e. on the value of GDP. In addition to import, export also has a statistical influence on the regression equation, whereas the statistical significance is somewhat less pronounced with the FDI variable.

\section{REFERENCES}

[1] Lovrić, M., Komić, J., Stević, S., 2017., Statistics Analysis - Methods and Application (orig. Statistička analiza-metodi i primjena), $2^{\text {nd }}$ abridged edition, Public Institution - National and University Library of the Republic of Srpska, Banja Luka.

[2] Malešević, Đ., Starčević, V., 2010., Business Analysis (orig. Poslovna analiza), University of East Sarajevo, Faculty of Business Economics in Bijeljina.

[3] Mikić, Đ., Ralević, N., 2006., Statistics Methods in Management (orig. Statističke metode u menadžmentu), PanEuropean University Apeiron, Banja Luka.

[4] The World Bank, http//data.worldbank.org/indicator

[5] http://www.bg.ac.rs/files/sr/studije/studije-uni/Uvod_statisticke_metode_istrazivanja.pdf

[6] http://www.ef.uns.ac.rs/Download/statistika/

[7] http://www.e-statistika.rs/Article/Display/korelacija-i-regresiona-analiza

[8] https://e-statistika.rs/Article/Display/korelacija-i-regresiona-analiza

[9] https://unctad.org/en/PublicationsLibrary/wir2012_embargoed_en.pdf,

[10] https://unctad.org/en/PublicationsLibrary/wir2018_en.pdf

Citation: Goran Mitrović, Slobodan Subotić. "Analytic Approach to Assessment of Interdependency of Economic Indicators (Statistical Method)" International Journal of Managerial Studies and Research (IJMSR), vol 7, no. 11, 2019, pp. 28-37. doi: http://dx.doi.org/10.20431/2349-0349.0711004.

Copyright: () 2019 Authors. This is an open-access article distributed under the terms of the Creative Commons Attribution License, which permits unrestricted use, distribution, and reproduction in any medium, provided the original author and source are credited. 